\title{
NOTES ON SOUTH AFRICAN CYCADS.*-1.
}

\author{
(With Plates VI., VII., VIII.)
}

\author{
By H. H. W. Pearson, M.A., F.L.S.
}

(Read June 27, 1906.)

While the Cycads have been the object of much attention from the anatomical botanist and, particularly during recent years, from the morphologist, our knowledge of what may be termed the Natural History of the group remains very imperfect. It is most desirable that some attempt should be made to lessen our ignorance in this respect, not only on account of the interest which attaches to this family as the most primitive of living seed-bearing plants, but also in the hope that a study of the living plants in a state of nature and of the life-conditions to which they have become adapted will throw light upon problems presented by the imperfect remains of their extinct relatives. Our present state of comparative ignorance is due, however, to no lack of interest, but rather to want of the opportunities for investigation. Cycads for the most part inhabit districts in which means of communication are few, and it is only here and there that systematic field-observations are possible. It has thus arisen that for what we know of the family as living plants we are chiefly indebted to the horticulturist.

Although, as Lehmann quaintly observes, "Cycadeæ omnes, quae Africam australem inhabitant, neque in agris urbi Capensi propioribus, neque in omnibus totius coloniae partibus proveniunt, sed in iis tantum terrae tractibus, qui longo intervallo ab urbe absunt," nevertheless the localities of many species are fairly easily accessible and offer facilities for investigation. The following paper contains records of observations on four of these species. Some are of doubtful significance, and may prove to be unimportant. They

* Assisted by a grant from the British Association. 
are deemed worthy of publication as a contribution to a body of facts from which in time valuable inferences may be drawn. As will be evident, much of the information contained in this paper is furnished by correspondents who are able to pay frequent visits to one or other of the forms considered, and to whom I am deeply indebted.

The species studied are Encephalartos Friderici Guilielmi, Lehm., E. Altensteinii, Lehm., E. villosus, Lem., and a species of Stangeria.

\section{Encephalartos Friderici Guilielmi, Lehm.*}

\section{(Plate VI., fig. 1.)}

The species which is believed to bear this name is abundant on the dolerite ridges in the Queenstown and Cathcart districts. It does not extend further north than Hangklip (6,500 ft.), and can be followed in a southerly direction almost as far as the eastern continuation of the Amatola range. Drège collected specimens on the Windvogelberg, a long ridge which overhangs the town of Cathcart. These were apparently identified by Lehmann as E. Friderici Guilielmi (fide De Candolle), which was later reduced to E. cycadifolius (Zamia cycadifolia, Jacq.). While, however, Lehmann's figures and description of the cones of E. Friderici Guilielmi contain nothing which would exclude those of the species now under consideration, the description of $E$. cycadifolius as given by De Candolle is not applicable to them. It seems, therefore, that the name should be retained for this species, though the point must remain doubtful until reference can be made to literature not accessible in South Africa.

This species is a marked sun-plant growing under conditions of extreme insolation. Occasionally, as, for example, on the steep banks of the Thomas River near the railway bridge, it is found in the neighbourhood of water, but in all cases its habitat is such as to demand a high degree of adaptation to xerophytic conditions. The plant branches freely, chiefly from the subterranean part of the stem, and consequently the occurrence of "clumps" consisting of plants of various sizes is very characteristic. The trunk attains a height of 12 to $15 \mathrm{ft}$., and then gradually falls over to a recumbent or prostrate position, in which it still produces new leaves and cones apparently as readily as when it stood erect. Branching sometimes occurs above ground (Plate VI., fig. 1). The removal of a thin layer of

* In the study of this species I have received much valuable assistance from my friend Mr. E. E. Galpin, F.L.S., of Queenstown. 
soil from the base of the trunk exposes a dense mass of apogeotropic roots of the usual type. It was hardly to be expected that they would be so abundantly developed in such a loose, dry soil.

Cones are produced freely, but, so far as can be ascertained, none of the plants on the ridges near Queenstown coned in 1905; the majority then bore old cones in a more or less disintegrated condition. Each crown bears a whorl of 4 to 6 cones (Plate VI., fig. 1), and both they and the crown are clothed with a particularly dense tawny wool (" tomento triticei coloris," Lehmann) - a condition which leads one to wonder how the pollen escapes from the male cone or gains entrance between the sporophylls of the female. The photograph reproduced was taken in September, 1905. Eight months later the cones had fallen away, and from the summit of the stem a new crown of leaves had arisen.

Owing to the comparatively high latitude of the locality of this species, its proximity to the lofty Stormberg-Drakensberg range, its distance from the sea, and its high altitude-4,700 ft. and perhaps even higher-it is probably exposed to stronger illumination and to a greater range of temperature than any other South African Cycad. Some idea of the climatic conditions may be gathered from the meteorological data for Queenstown (situated somewhat to the north of the centre of its area of distribution), which are given at the end of the paper. The range of temperature to which most members of this species are subjected must be considerably greater than that disclosed by the Queenstown records. While the dense tomentum which clothes the cones is perhaps an adaptation to this condition, it is not unlikely that the species is further adapted by modifications in certain stages of its life-history-as, for example, by a shortening of the periods of the development and germination of the pollen. Fertilisation must very generally occur, for in September 1905, seeds with well-developed embryos were abundant. A detailed study of its life-history therefore promises results of unusual interest, and will be undertaken when the next crop of cones appears.

Encephalartos Altensteinit, Lehm.

(Bot. Mag. tt. 7162, 7163.)

(Plates VI., fig. 2; VII., fig. 1.)

In the bush which clothes the steep banks of the rivers entering the sea in the neighbourhood of East London occurs the well-known arborescent Encephalartos Altensteinii. It is found in sunny situations in the more open bush (Plate VII., fig. 1), or clinging 
to the precipitous rock-faces overhanging the rivers, or, perhaps more frequently, in the dense shade of the forest (Plate VI., fig. 2). Very commonly associated with it, particularly in shaded localities, is the epiphytic fern Polypodium africanum.

Vegetative reproduction by subterranean branching is much less common than in E. Friderici Guilielmi. Branching above the ground-level is frequent, but, so far as I have seen, occurs only in specimens exposed to sunlight and growing not far from water. In the type usually met with the main trunk has maintained its vertical direction, while a lateral branch, at first almost horizontal, curves upwards and becomes parallel with its parent (Plate VII., fig. 1). A very remarkable case of branching may be seen on the steep left bank of the Nahoon River, some $20 \mathrm{ft}$. above water-level. Six lateral branches and a large bud arise from the main trunk about 3 to $4 \mathrm{ft}$. above the ground. Four or five feet higher up is the leafless top (May 1906) of the main trunk, and, just below it, five other stout branches and a multitude of undeveloped adventitious buds. The branches are all as thick or thicker than the main trunk. On one branch were the remains of a male cone. We have here a single plant bearing eleven crowns of leaves, and with every indication that its potentiality of branching: is not yet exhausted. It will bear comparison with the old branched tree of Cycas circinalis represented in Kittlitz's picture (Treas. Bot., pl. vi.), though in point of size it falls far behind the specimen seen in Natal by Sanderson and referred to by Sir Joseph Hooker in his account of this species (Bot. Mag., l.c.). The asclepiad Tylophora syringrefolia was epiphytic on two branched specimens of this Cycad; its tuberous stem-base was so tightly wedged in the angle between the branch and the main stem that it could not be removed entire.

No cones nor vestiges of cones were found on plants growing in the dense bush (May 1906). A minority of those exposed to sunlight shewed remains of male or of female cones, but no young nor perfect cones of either sex were seen. The production of cones by this species in this locality must be much less frequent than in E. Friderici Guilielmi. It may be noted that plants of E. Altensteinii under cultivation in Cape Town, far to the west of the eastern limit of the species and subject to very different climatic conditions, usually cone with great regularity at intervals of about two years. On the other hand, the cone figured in the Botanical Magazine (l.c.), from a plant grown near Norwich, appeared thirteen years after the one which immediately preceded it.

There is current a general statement that, except in the genus 
Cycas, the cones are terminal on the stem, and that the latter in consequence becomes a sympodium. This is not true for Encephalartos Friderici Guilielmi nor for E. Altensteinii. In both cases we have in both sexes a group of three to six * cones arranged symmetrically round the apex (Plate V., fig. 1.). Later, when the apex resumes growth, the cones are displaced radially, and the next crown of leaves appears in the centre of the whorl of cones. It is clear, therefore, that in these species the summit of the vegetative cone remains vegetative and continues the growth of the stem.

\section{Encephalartos villosus, Lem.}

(Bot. Mag. t. 6654.)

(Plate VII., fig. 2.)

This species is quite as abundant as E. Altensteinii in the East London bush. It appears that it is confined to shady situations (Plate VII., fig. 2), and never occurs on the open veld. The stem, said to be "rarely developed in imported and cultivated specimens" (Thiselton-Dyer in Bot. Mag., l.c.), seems to be always subterranean in its native bush; it is large and tuberous, and is covered by stout leaf-bases. The scale-leaves are densely villous. Apogeotropic roots arise from the top of the main root. Its leaves are longer and fewer in number than those of E. Altensteinii, but in other respects resemble them. Its range is extensive. It occurs in Natal, where, as I am informed by Mr. Medley Wood, "it is always found in shade, and the trunk never appears above the ground;" at Kentani in the Transkei (Miss Pegler); abundantly in the neighbourhood of East London; and I have received a cone from Messrs. Smith Bros., of Uitenhage, though I do not know that it occurs in the wild state so far west as this. Mr. James Sim writes that between East London and Kingwilliamstown it does not extend more than 20 miles inland.

In some localities at least this species rarely cones under natural conditions. Miss Pegler has sent me one male cone from Kentani, and has informed me of the existence there of another and of a plant surrounded by young seedlings; she states, however, that "cones are rare." From Mr. J. Sim I have also received a female cone obtained in the Grey Forest, East London. Messrs. Wood and Rattray, of East London, who have the plants in the immediate neighbourhood under constant observation, have never found cones,

* But sometimes, apparently, in E. Friderici Guilielmi, the cone "ex apice caudicis solus egreditur et erectus" (Lehmann). 
and I was unable to find any traces of them, though Mr. Rattray drew my attention to an old plant around which were growing a considerable number of small ones, apparently seedlings. On the other hand I found a male cone on a plant growing in a fairly open situation in the Queen's Park at East London, and saw a coning female in the garden of Mr. W. Smale, of East London. Mr. Smale, who has known this plant for fifteen years, informs me that, with one or perhaps two exceptions, it has produced cones annually. In cultivation in the northern hemisphere cones " have been repeatedly produced" (Thiselton-Dyer, l.c.).

Miss Pegler has made the following observations on the rate of growth of a male cone on a wild plant growing on the bank of a stream-bed (usually dry) in the Kentani forests :-

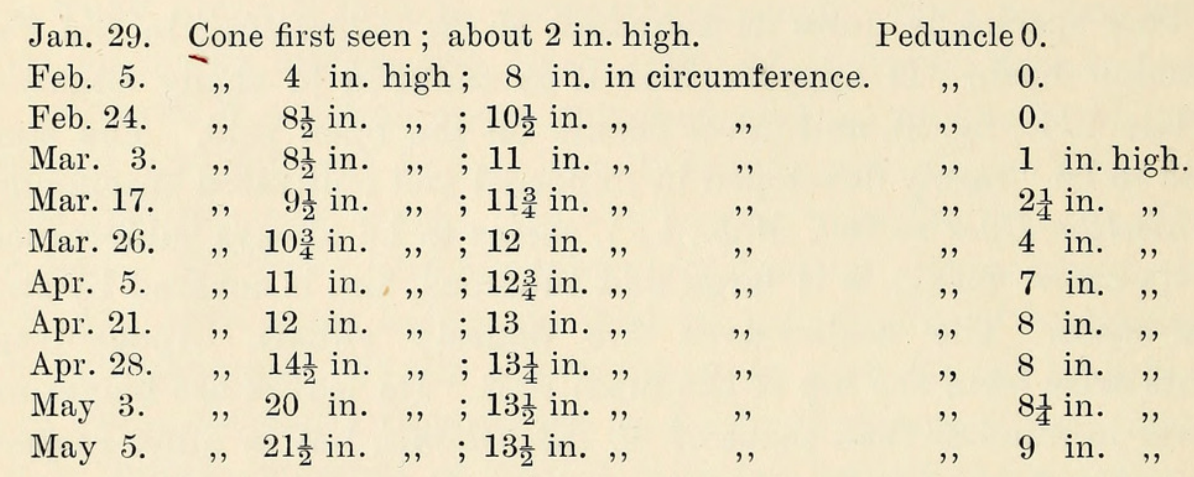

On April 5th the sporophylls began to separate, and on May 5th they were open to their fullest extent and the pollen was falling freely. See Text-fig. 1.

The cone therefore shewed two distinct periods of growth, viz., from January 29th to February 24th, and from April 5th, when the sporophylls began to separate, until its elongation ceased on May 5th. During the intervening period of forty days the most rapid elongation of the peduncle occurred while the axis of the cone itself added only $2 \frac{1}{2}$ in. to its length. In Stangeria and in other species of Encephalartos it is ascertained that the microsporangia contain adult pollen-grains when the sporophylls begin to separate. It may therefore be assumed that during the forty days in which the elongation of the cone-axis was exceedingly slow, the development of the pollengrains from an early condition of the archesporium was taking place. The greatly accelerated increase in length which occurred after April 21st may possibly have been influenced by a three days' rain, which fell between that date and April 28th, though the growth of the peduncle was not appreciably affected by it. 


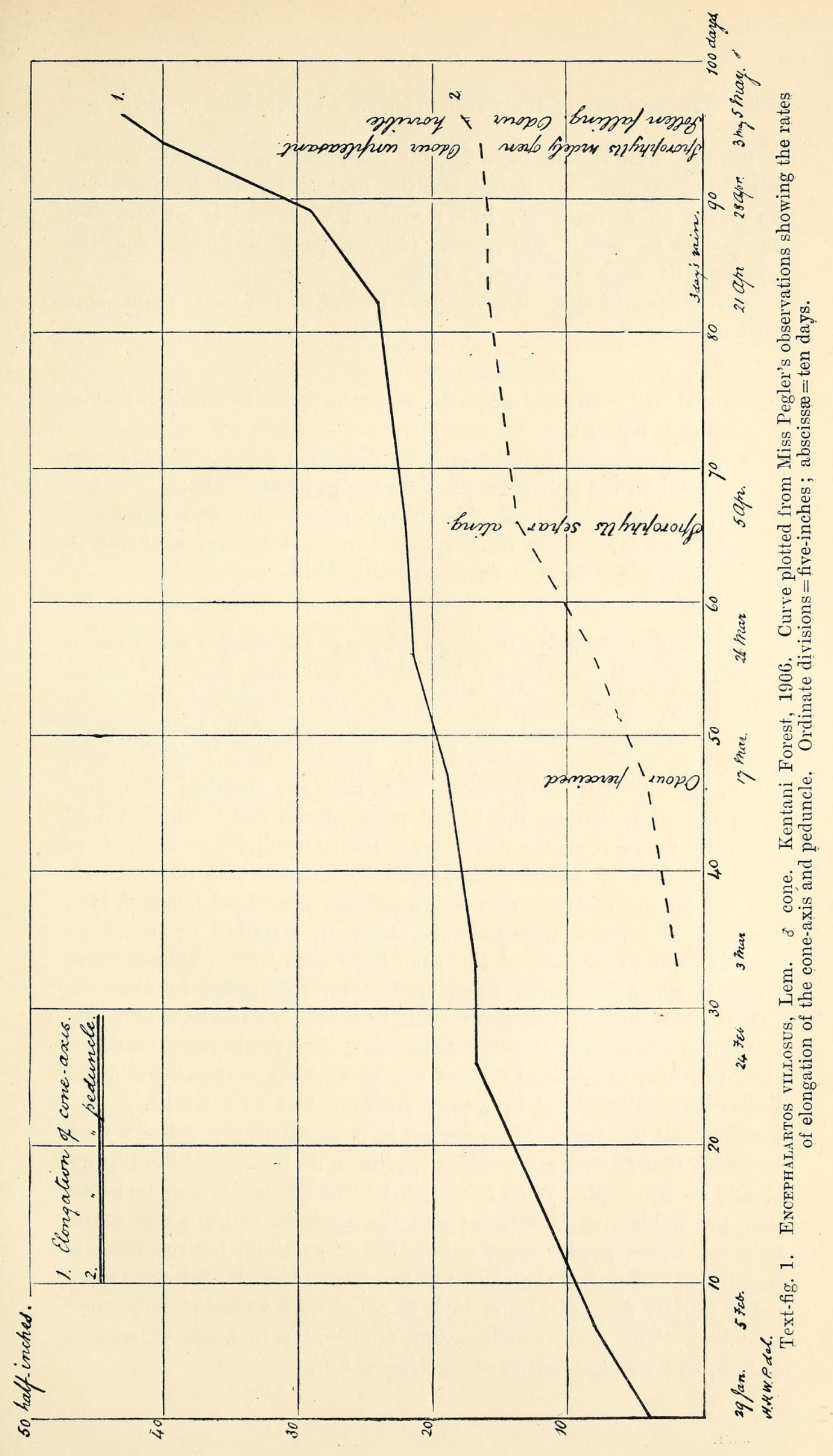


Similar observations have not yet been made on a female cone in a state of nature. Mr. Smale saw the first sign of the cone referred to above on January 23, 1906; when I examined it on May 3rd it was 15 in. out of the ground (i.e. cone and peduncle) and the sporophylls were still closely shut.

Miss Pegler further observed with regard to the same male cone that on-

March 17th the cone emitted a pleasant odour resembling that of fresh honey;

May 3rd the odour had become unpleasant; several weevils were seen on the pollen-sacs but could not be captured;

May 5th the odour was "horrible," penetrating and persistent. The weevils seen on May 3rd were no longer present, but in their place were many of a smaller kind.

Miss Pegler was able to capture several of the smaller weevils seen on May 5th. Mr. Péringuey has kindly identified these for me as Phlceophagus hispidus, Schh. This, and another species of the same genus, P. ebeninus, Schh., were among the numerous beetles which Ecklon and Zeyher collected "in Zamia Caffræ" (Schoenherr, 1,049, 1,051). All the specimens of P. hispidus obtained from this cone carried pollen on the hispid parts of the body, which would naturally follow from the condition of the sporophylls on the date of their capture. In addition there was a compact mass of pollen on the tip of the rostrum of every specimen examined (Plate VIII., fig. 1). The mass was securely attached, possibly by mucilage exuded from the tissues of the cone itself with which, indeed, other parts of the insect were besmeared. Mr. Péringuey informs me that the members of this genus usually feed upon the bark of trees, and all are winged. P. hispidus has at present only been found on Cycads. Too much stress must not be laid upon these few facts, but it may be admitted that they are sufficient to establish a probability that the weevil is concerned in pollination, and make it very desirable that further information regarding its habits and life-history should be obtained. With reference to this matter, it may be noted that the habitat of $E$. villosus and the position of its cones must, in most cases, render wind-pollination impossible, for the bush is usually so dense that the air a few feet above the ground can rarely move rapidly enough to enable it to carry even so light a substance as pollen. The same consideration applies, but in a somewhat less degree, to forest specimens of E. Altensteinii. 
Strasburger discussed the pollination of the gymnosperms, and arrived at the conclusion, which has been generally accepted, that anemophily holds throughout the group. There are, however, indications that entomophily occurs in the Gnetaceæ (Pearson). On the ground that so many pollen-grains are found in the chamber of a pollinated ovule, Sir Joseph Hooker has recently suggested that the Cycads also are entomophilous (Oliver and Scott). This suggestion is supported by the facts now recorded as well as by the observation that a strong odour is developed in the male cones of a Cycas, * and probably also in other members of the family. That a very large proportion of the ovules of a cone become pollinated + must be regarded as additional evidence, for if the pollen were entirely windcarried it might reasonably be expected that only those situated on the usually windward side of a bulky cone would receive pollen. So far as I am aware there are no records to show that this is ever the case. The whole question derives additional interest when considered in the light of the recently described structure of the cupule of the seed of the palæozoic Pteridosperm Lagenostoma Lomaxi (Oliver and Scott). It seems not unlikely that the entomophilous habit is of considerably older standing than has hitherto been believed. In this connection the fact that the group to which the genus Phlæophagus belongs includes what the entomologists regard as the most ancient surviving forms of the Coleoptera may not be without significance.

\section{Stangeria, sp. \\ (Plate VIII., figs. 2, 3.)}

Among the grasses of the park-formation on the tops and upper slopes of the ridges near East London is found a species of Stangeria. Its distribution is very local, but where it does occur it is present in considerable numbers. It is present also, but sparingly, in the neighbouring bush. This form occurs also in the open country at Kentani (Miss Pegler), and as far west as Port Elizabeth (Rattray). It differs from $S$. paradoxa of the Botanical Magazine (t: 5121), which in Cape Colony seems to be confined to the forest, though

* At present I know of no published record of this observation. I am indebted to Professor D. H. Campbell for the information.

1 A large number of ovules removed at random from a cone of E. Altensteinii, from Amalinda, near East London, were dissected and the pollen-chambers fixed. Nearly all this material has been examined, and, so far, every ovule has proved to be pollinated. 
forms which are more or less intermediate are occasionally found. The principal differences expressed in tabular form are:-

Stangeria, sp.

Petiole and rachis grooved on ventral face.

Great majority of leaf-segments with rounded or obtuse apices. Margin of leaf-segment in great majority, entire and revolute. Upper margin of sporophyll ( $\delta$ and $q$ ) usually rounded.
S. paradoxa (B.M., t. 5,121).

Petiole and rachis terete.

Apex of leaf-segment acuminateacute.

Margin usually flat and distinctly serrate.

Upper margin of sporophyll usually more or less acuminate.

While the form characteristic of the open grass-veld is so distinct from that of the forest that one would not hesitate to regard them as different species, it must be admitted that the occasional appearance of a form to some extent intermediate between the two necessitates a fuller knowledge of both before a definite conclusion can be arrived at. The form occurring on the open grass-veld of East London and Kentani is usually known here as S. Katzeri (Regel), though neither the identification nor the claim of S. Katzeri to rank as a species is, in my opinion, sufficiently established. Mr. Medley Wood writes to me of plants which "I have frequently seen in Zululand ... on the hillsides in quite open ground," and "the only difference which I can see between them and S. paradoxa is that the leaves, or some of them, are often slightly serrated, while those of plants growing in the shade are entire "-which is the reverse of our experience further south. The current statement that Stangeria is a monotypic genus can only be proved or disproved by the study of a large number of specimens from many different localities.

The forest-form of $S$. paradoxa, as is well known, was first described from Natal specimens. It is also recorded from East Pondoland (T. R. Sim, 2,490!), and occurs as far south as the Manubi Forest (Pegler, 1,247!), from which locality I have received an exceedingly interesting collection of male cones in various stages of development kindly obtained for me by Mr. S. Allen, of the Manubi Forest Station. These will form the subject of a separate paper.

The following remarks refer to plants growing on the open veld near East London. The stem is entirely subterranean and appears to branch profusely. Mr. Rattray has kindly been at the trouble to excavate a number of specimens, and finds that branching occurs quite commonly. The specimen figured (Plate VIII., fig. 3), which 
was sent to me by Mr. Rattray, shows three main branches, of which one (on the left) already shows clear indications of further branching. The whole stem is undoubtedly a sympodium. Remarkable as this specimen appears, Mr. Rattray referring to it says, "Even the specimen I sent gives you but little idea of the extent to which they branch. To-day I started to dig up what I hoped was a young plant, and found it to be only a small branch of quite a number." This habit will account for the fact that the plants are-so frequently found in clumps. Each stem (or branch) produces one or two leaves and, so far as I have seen, never more than one cone (cf. Bot. Mag., l.c.), which arises from an involucre of scale-leaves. The cone stands a few inches above the ground, and is only seen on removing the surrounding grasses (Plate VIII., fig. 2.). The peduncle is sometimes six or more inches long, its length being probably dependent upon the height of the surrounding vegetation (Plate VIII., fig. 3). Specimens sent me by Mr. Wood from the vicinity of the Nahoon River show that the foliage also of plants growing among tall grasses becomes taller and more robust. The fact that the cones are concealed among the grass is opposed to the view that wind-pollination occurs. Further information with reference to this matter will, it is hoped, be forthcoming. Apogeotropic roots are usually found and are inhabited by a Nostoc. Their development is less marked than in Encephalartos Friderici Guilielmi, which grows in a drier soil.

\section{SUMMARY.}

1. Subterranean branching is a marked feature of Encephalartos Friderici Guilielmi and of Stangeria. In both cases it plays a part in vegetative reproduction not less important than in many ferns with subterranean rhizomes.

2. The cones are lateral in position in E. Friderici Guilielmi and in E. Altensteinii, and the growth of the stem is in both cases monopodial.

3. E. Friderici Guilielmi, which is subject to strong insolation, cones much more freely than either E. Altensteinii or E. villosusboth, especially the latter, being shade-species.

4. In E. Altensteinii cones are not infrequent on plants growing in more or less open positions exposed to sunshine. As far as is known they occur very rarely, if at all, on plants in densely shaded situations. A few observations support a similar conclusion for E. villosus (cf. Pfeffer, pp. 91, 92).

5. It is probable that other exceptional conditions such as are 
implied in cultivation also act as a stimulus to the production of cones.

6. In E. Altensteinii branched specimens seem to occur only in illuminated situations ( $f f$. Pfeffer, p. 93), and usually if not always, near water-conditions which are both favourable to nutrition.

7. There is a distinct probability that entomophily occurs in E. villosus. The position of the cones of Stangeria with respect to the surrounding vegetation points to the inefficiency of the wind as a pollinating agent.

Botanical Laboratory,

South African College.

METEOROLOGICAL DATA FOR QUEENSTOWN AND EAST LONDON.*

\begin{tabular}{|c|c|c|c|c|c|c|c|c|c|}
\hline & 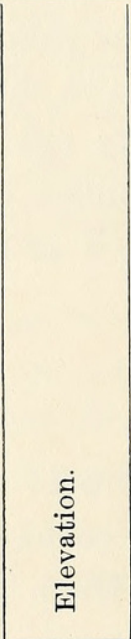 & 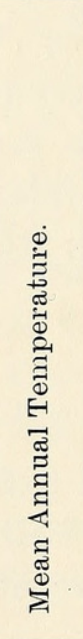 & 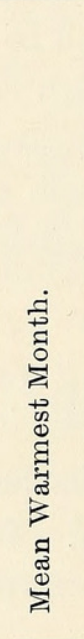 & 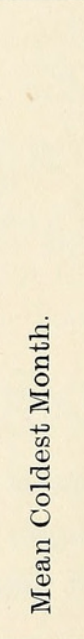 & 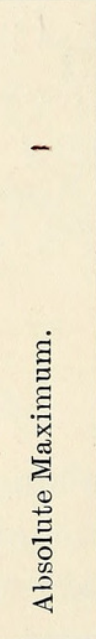 & 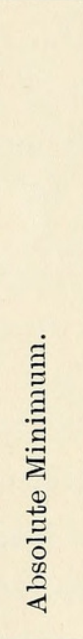 & 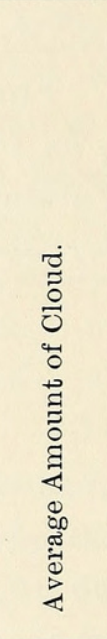 & 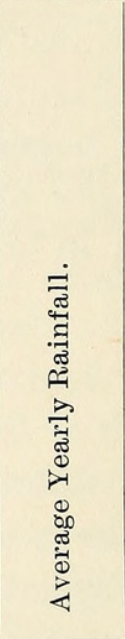 & 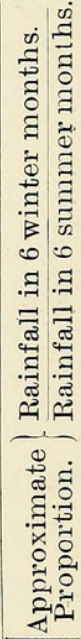 \\
\hline Queenstown ... & $3,500 \mathrm{ft}$. & $61 \cdot 4^{\circ}$ & $69 \cdot 9 \circ$ & $51 \cdot 2$ & $104 \cdot 0^{\circ}$ & $19 \cdot 0^{\circ}$ & $36 \cdot 6 \%$ & $26 \cdot 9$ in. & $\frac{1}{3}$ \\
\hline East London ... & $20 \mathrm{ft}$. & $64 \cdot 8^{\circ}$ & $70 \cdot 0^{\circ}$ & $60^{\circ} 0^{\circ}$ & $101 \cdot 0^{\circ}$ & $37 \cdot 0^{\circ}$ & $49 \cdot 0 \%$ & & $\frac{2}{3}$ \\
\hline
\end{tabular}

* Chiefly from Stewart, 1905. 


\section{BIBLIOGRAPHY.}

De Candolle. Prodromus, vol. xvi., part 2 (1868).

Hooker, J. D. Curtis's Botanical Magazine (1882, 1891).

Hooker, W. J. Curtis's Botanical Magazine (1860).

Lehmann, J. G. C. De Plantis Cycadeis praesertim Africae Australis (1834).

Lindley, J., and Moore, T. Treasury of Botany (1870).

Oliver, F. W., and Scott, D. H. On the Structure of the Palæozoic Seed Lagenostoma Lomaxi, \&c. Phil. Trans., B, v.ol. 197 (1904), pp. 193-247.

Pearson, H. H. W. Some observations on Welwitschia mirabilis, Hooker, f. Phil. Trans., B, vol. 198 (1906), pp. 265-304.

Pfeffer, W. The Physiology of Plants (Eng. Trans.), vol. 2 (1903).

Schomnherr, C. J. Genera et species Curculionidum, \&c. Tom. iv. Pars. 2 (1838).

Stewart, C. M. The Meteorology of South Africa. Science in South Africa (1905), pp. 19-60.

Strasburger, E. Die Coniferen und die Gnetaceen (1872). 


\section{EXPLANATION OF PLATES.}

\section{Plate VI.}

Fig. 1. A branched tree of Encephalartos Friderici Guilielmi growing on the top of a ridge (4,700 ft.) above Queenstown, with an unbranched specimen in the middle distance on the right. The branch on the left shews a whorl of 5 disintegrating $\delta$ cones, and the well-marked alternation of scale- and foliage-leaves. The doleritic boulders among which this species flourishes are also seen (September 23, 1905).

Fig. 2. E.Altensteinii in dense bush on the left bank of the Buffalo River near East London. Among the leaf-bases are numerous plants of the epiphytic Polypodium africanum. The walking-stick leans against the trunk of Trichocladus ellipticus. A young plant of Buxus MacOwani is seen at the base of the trunk of the Encephalartos. A little higher up, placed horizontally and slightly out of focus, are flowering branches of Niebuhria triphylla (April 30, 1906).

\section{Plate VII.}

Fig. 1. Encephalartos Altensteinii, in open bush on the right bank of the Nahoon River. In front of the branched trunk is a stem of the deciduous Commiphora caricefolia (May 2, 1906).

Fig. 2. E. villosus, growing a few yards from the E. Altensteinii, shown in Plate VI, fig. 2. In the foreground in front of the walkingstick is an uprooted young plant showing the tuberous stem covered by leaf-bases (April 30, 1906).

\section{Plate VIII.}

Fig. 1. Rostrum of Phløophagus hispidus with adherent pollen from $\delta$ cone of Encephalartos villosus, $\times 56$.

Fig. 2. Stangeria, sp. Two leaves and a $\delta$ cone. Grass-veld near East London (May 2, 1906).

Fig. 3. Stangeria, sp. (ð), from the same locality, showing underground branching. In front of the specimen lie a $\bar{\sigma}$ cone (obtained by Mr. Rattray "among long grass") and a footrule. (Photographed by Mr. W. T. Saxton.) 


\section{$2 \mathrm{BHL}$ Biodiversity Heritage Library}

Pearson, H H W . 1905. "NOTES ON SOUTH AFRICAN CYCADS.-1."

Transactions of the South African Philosophical Society 16, 341-354. https://doi.org/10.1080/21560382.1905.9526070.

View This Item Online: https://www.biodiversitylibrary.org/item/113609

DOI: https://doi.org/10.1080/21560382.1905.9526070

Permalink: https://www.biodiversitylibrary.org/partpdf/175338

\section{Holding Institution}

Field Museum of Natural History Library

\section{Sponsored by}

The Field Museum's Africa Council

\section{Copyright \& Reuse}

Copyright Status: NOT_IN_COPYRIGHT

This document was created from content at the Biodiversity Heritage Library, the world's largest open access digital library for biodiversity literature and archives. Visit BHL at https://www.biodiversitylibrary.org. 